\title{
Assessment of the terrestrial impact of a nuclear power plant caesium 137 and caesium 134 atmospheric releases
}

\author{
S. Gazal ${ }^{1}$ and R. Prangé ${ }^{2}$ \\ ${ }^{1}$ UFR des Sciences de la Vie et de la Terre, Université Paul-Sabatier, 31400 Toulouse, \\ France - Commission Locale d'Information auprès du CNPE de Golfech, Conseil Général de \\ Tarn-et-Garonne, 82013 Montauban, France, e-mail: gazal@univ-tlse2.fr \\ ${ }^{2}$ LESIA, Observatoire de Paris, 92195 Meudon, France, e-mail: renee.prange@obspm.fr
}

\begin{abstract}
Terrestrial contamination by ${ }^{137} \mathrm{Cs}$ and ${ }^{134} \mathrm{Cs}$ since 1986 in France is held to originate in atmospheric nuclear weapon tests and/or the releases from the Chernobyl accident. Monthly measurements of radioactivity in terrestrial mosses are part of the monitoring protocol carried out by the Conseil Général of Tarn-et-Garonne to assess the environmental impact of the Golfech nuclear power plant radioactive releases. Since the commissioning of the NPP in 1990, these monthly measurements revealed a contamination by ${ }^{137} \mathrm{Cs}$ and ${ }^{134} \mathrm{Cs}$ (up to 700 and $60 \mathrm{BqKg}^{-1} \mathrm{DW}$ ) in both sampling sites. This contamination decreased by a factor about 10 over $1990-2004$ through three stages $\left({ }^{134} \mathrm{Cs}\right.$ undetectable since 1995). It is significantly correlated over large periods of time with the monthly levels of atmospheric halogens-aerosols releases by the Golfech NPP $\left(95 \%, \mathrm{r}^{2}=0.35\right.$ to $\left.>0.84\right)$. These results are discussed in the light of the time since radioactive releases, of the operating and release conditions of/from the Golfech NPP and of the mosses sampled. These preliminary results bear evidence of an impact of the Golfech NPP on the terrestrial environment. They confirm that species of terrestrial mosses are particularly sensitive to low levels of atmospheric radioactive caesium contamination and are a good indicator of a radioactive fallout. They suggest that terrestrial mosses may serve to elaborate a predictive model of a caesium release, together with some relevant parameters and in the framework of a carefully defined monitoring protocol.
\end{abstract}

\section{INTRODUCTION}

Mosses are known to concentrate environmental aquatic and atmospheric trace elements, stable or unstable, natural or anthropogenic.

This ability originates in various factors, related to the plant (morphology, metabolism, moss-carpet), to the elements concerned (electronic and nuclear properties, physical and chemical forms), to the environmental conditions (dynamics of the physical systems, substratum, elements concentrations) and their interactions $[1,7]$.

Numerous studies have been carried out on the contamination of mosses from atmospheric radioactive trace elements, either natural and/or anthropogenic, such as ${ }^{137} \mathrm{Cs}$ and ${ }^{134} \mathrm{Cs}$.

Although inter-calibration of moss spp. concentration capacities are lacking, correlations have been pointed out between caesium concentrations in mosses and some parameters, which may be accounted for by the above factors. One can mention a limited range of variations of the concentration power of ${ }^{137} \mathrm{Cs}$ and ${ }^{134} \mathrm{Cs}$ (ratio 2-3) in similar environmental conditions [14,2], except for Sphagnum spp. ( 5-10 fold less contaminated), a captation increase with altitude [27,32,9,23,5,19], with the inclination (inclined < vertical < horizontal) [12,16], the density and the thickness [12,5] of the moss carpet, a positive Kd between leaves and stems [11], a decreasing concentration of ${ }^{137} \mathrm{Cs}$ with the growth rate [16,26], a higher concentration in older parts of Hylocomium splendens [18] and a 
significant attraction of N, K and P for young stems' leaves observed in five Sphagnum species [20], in the context of $\mathrm{a}^{137} \mathrm{Cs} /{ }^{40} \mathrm{~K}$ or total $\mathrm{K}$ competition $[2,10,4,32,25,21]$, a primary concentration of intra-cellular caesium in cell-walls liable of ionic exchanges [6,8], an increase of intra-cellular, or on the contrary the migration of intra-cellular potassium and an increase of the bioavailability of extra-cellular potassium with the level of desiccation [3], in the context of a ${ }^{137} \mathrm{Cs} / \mathrm{K}$ ratio higher in dead material than in living one in Pleurozium schreberi [21]. However, the edaphic influence of the medium on caesium captation by mosses $[9,27,14]$, as well as the influence of the sampling location (such as its position relating to a forest canopy) $[14,12]$ remain controversial. Furthermore, there is almost no evidence of a correlation between caesium contamination in mosses and precipitations [14] or wind, and data related to effective or biological half-lives of ${ }^{137} \mathrm{Cs}$ are scarce and not consistent. Authors suggest either an exponential model (Polytrichum juniperinum $\mathrm{P}_{\text {eff }} \sim 2.2$ years at $44^{\circ}$ north latitude extrapolated from [30], Ctenidium molluscum $\mathrm{P}_{\text {eff }} \sim 46$ months [12], $\mathrm{T}_{\text {eff }} \sim 49,2$ days [29]) or a linear model $\left(\mathrm{P}_{1 / 2} \sim 1.6\right.$ years in $\left.[26,14]\right)$. It is however acknowledged that such data are highly dependant on the local conditions such as time since the release and the distance to the source, as well as on the moss spp. and the environmental conditions. No data are available to this respect concerning ${ }^{134} \mathrm{Cs}$. Few data are available concerning caesium accumulation time. either. It has been estimated $\sim$ a few years [26,24], or less than a year [14] in the aftermath of the Chernobyl accident.

As far as ${ }^{137} \mathrm{Cs}$ and ${ }^{134} \mathrm{Cs}$ are concerned, air pollution has three main sources: atmospheric nuclear weapons tests, releases from nuclear facilities such as research centres, NPPs and reprocessing facilities, both routine and accidentally (the main contribution to-day being the Chernobyl accident). Apart from a study carried out in the vicinity of the Sellafield reprocessing facility [28], and yearly measurements by [17] on a few moss samples collected in NPPs' surroundings on behalf of Electricité De France (EDF), available studies of mosses contamination by ${ }^{137} \mathrm{Cs}$ and ${ }^{134} \mathrm{Cs}$ are related to atmospheric weapons tests and/or the Chernobyl accident.

Measurements of radioactivity in terrestrial mosses is part of the monitoring protocol carried out by the Laboratoire Vétérinaire Départemental de Tarn-et-Garonne (Conseil Général de Tarn-et-Garonne) to assess the environmental impact of the Golfech nuclear power plant radioactive releases.

The aim of this study is to assess the possible correlation of the ${ }^{137} \mathrm{Cs}$ and ${ }^{134} \mathrm{Cs}$ measured in terrestrial mosses with the monthly levels of atmospheric radioactive releases from the Golfech NPP, and the extend to which these releases are liable to explain variations of the contaminations measured in terrestrial mosses.

\section{MATERIAL AND METHODS}

\subsection{The sampling and measurement protocols}

Two sampling sites have been selected in the vicinity of the Golfech NPP, in Lamagistère 1,5 km N-NO downwinds, and in Golfech $\sim 1 \mathrm{~km}$ E-NE from the facility.

Monthly samples have been collected and gamma spectrometry carried out since the commissioning of the NPP (May 1990), as well as reference measurements on both locations 71 and 365 days before this date respectively. 256 measurements are thus available (175 for Lamagistère and only 81 for Golfech due to an interruption over august1996-october 2003).

The mosses (living as well as dead parts, rhizoide) are gathered from a respectively horizontal and inclined concrete substratum, and have been regularly identified by the Société d'Histoire Naturelle du Pays de Montbéliard (Doubs) since January1992.

Fresh moss samples are packed into a $6.5 \mathrm{~cm}$ large x $8.5 \mathrm{~cm}$ high $200 \mathrm{ml}$ beaker. Gamma spectrometry is performed on an ARIES-TENNELEC co-axial high purity germanium detector with a $5 \mathrm{~cm}$ lead shielding, a $20 \%$ relative efficiency at $1332 \mathrm{keV}$ and a resolution in energy of $850 \mathrm{eV}$ and $1,80 \mathrm{keV}$ at $122 \mathrm{keV}$ and $1.33 \mathrm{MeV}$ respectively. Typical counting time for the samples is 8 hours. Pulses are analysed with a 4096 channels acquisition system. Then the samples are dried at $60^{\circ} \mathrm{C}$. The ${ }^{137} \mathrm{Cs}$ and ${ }^{134} \mathrm{Cs}$ measured values are decay-corrected to the sampling date, and the associated uncertainty is the total uncertainty associated with the measurement, including counting and efficiency calibration errors. The measured values are expressed in counts per kgDW (dry weight). Detection limits are $\sim$ a few $\mathrm{Bqkq}^{-1} \mathrm{DW}$. 


\subsection{The variables under study}

After empirical investigations, 30 days and 15 days releases calculated from a mean daily release (Lamagistère), and 45 days calculated releases as well as the month before the sampling date releases (Golfech) were selected. This data may be but considerably biased (the global monthly values available from the operator include varying and undetermined proportions of both halogens, mainly iodine, and aerosols, mainly cobalt and caesium, they are unequally distributed over the month, sampling days vary, mosses are known to retain contaminations over longer periods of time).

Both row values and corrected for decay of the weapon tests and of the Chernobyl accident values have been plotted against the NPP releases. Several decay models have been tested (physical half-life and [30,29] exponential models, [26,14] linear model). A mixed model has also been implemented (physical half-life model applied to the weapons tests contribution combined with linear model applied to the Chernobyl contribution).

\section{THE RESULTS}

\subsection{The moss contaminations}

The moss spp. sampled are different on each location. Bryum spp., Grimmia spp., Hedwigia ciliata and Didymodon fallax are dominant on the Golfech location, whereas the dominant species collected from Lamagistère are much more varied and free of Grimmia spp., Bryum capillare and Bryum argentum seldom occurring as dominant species.

The contaminations measured globally decreased over 1990-2004 by a factor $\sim 10$ through three stages (decrease less steady over time in Lamagistère than in Golfech throughout $1992-1996$, ${ }^{134}$ Cs undetectable since november 1991 and 1995 respectively) (Figure 1).

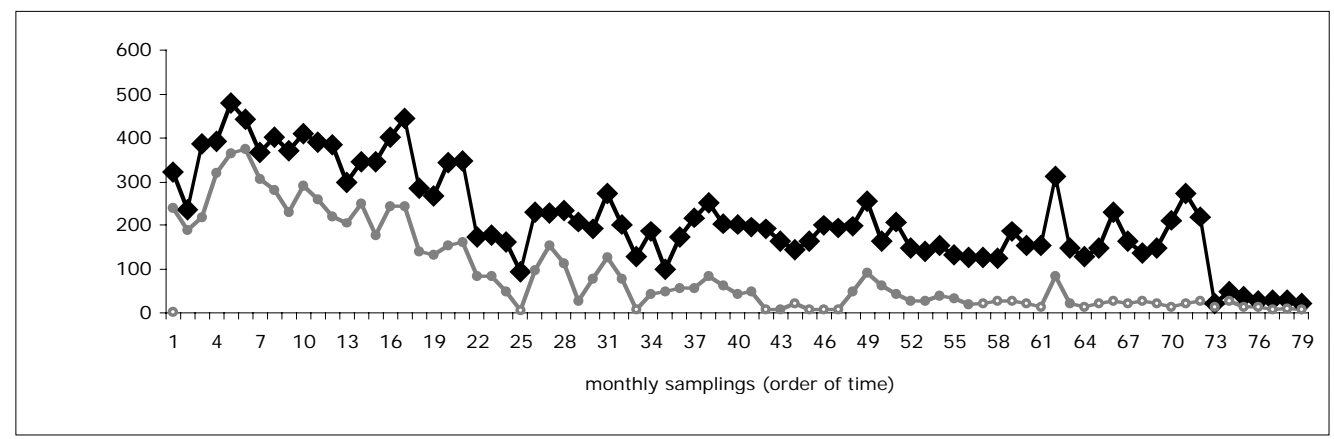

Figure 1. Caesium contaminations measured in mosses from Golfech over may 1990-may 2004.

The contaminations measured in Golfech are usually higher than those in Lamagistère by a factor 2-3 (mean values ratios 2.5 and 2.7, mean max. values ratios 1.8 and 2.5 , mean min. values ratios 2.75 and 4.75 for ${ }^{137} \mathrm{Cs}$ and ${ }^{134} \mathrm{Cs}$ respectively). The ${ }^{137 / 134} \mathrm{Cs}$ ratios measured in the reference samples (6.2 and 9.4) are rather consistent with the Chernobyl expected ratios (5.4 and 8). The deviation suggests both weapons tests and Chernobyl contributions (calculated 21 and $189 \mathrm{Bqkg}^{-1} \mathrm{DW}$, and 16 and $106 \mathrm{Bqkq}^{-1} \mathrm{DW}$ respectively).

\subsection{The releases/moss contaminations correlations}

Poorly significant correlations can be obtained over the whole period may1990-may2004 in either sampling site. However, significant correlations come out provided that various periods of time and different levels of measured contamination and of activities released are processed separately (p .05). 
Concerning Lamagistère ${ }^{134} \mathrm{Cs}$, the only data available concern the may1990-dec.1991 period (15 values after oct.1990 release peak removal). All models lead to very significant correlations when combined with calculated over 30 days releases $\left(\mathrm{r}^{2}=.73-.84\right.$, row $>$ linear $>$ exponential modals, 8 to 15 plots). The [30,29] exponential models also have a good fit with releases calculated over 15 days before the sampling dates $\left(\mathrm{r}^{2}=.74-.75\right)$ (Figure 2a). As far as ${ }^{137} \mathrm{C}$ is concerned, $\mathrm{r}^{2}=.35$ and .54 for the may 1990-dec.1992 and nov.1995-april 1998 periods (39 and 28 plots respectively and after removal of four release values higher than the usual ones by two orders of magnitude in the latter case) provided that the contamination row values are plotted against releases calculated over 30 days before the sampling dates (Figure 2b). A $\mathrm{r}^{2}=.55$ determination coefficient for the may 1990-dec.1991 period is not as high as for ${ }^{134} \mathrm{Cs}$. Moreover, release values higher than the usual values by one order of magnitude are significantly correlated with mosses ${ }^{137} \mathrm{Cs}$ contaminations over nov.1995-sept. $1998\left(\mathrm{r}^{2}=.49\right)$. No such correlation is available for the nov.1998-may2004 period $\left(\mathrm{r}^{2}=.28\right.$ for $\geq 3 \times 10^{4} \mathrm{kBq}$ releases). A noticeable correlation shows over the whole period (may1990-may2004) when $\geq 65 \mathrm{~Bq} / \mathrm{kg}^{-1} \mathrm{DW}$ moss contaminations are plotted against usual release values $\left(\mathrm{r}^{2}=.29,45\right.$ plots).

Concerning the Golfech location, ${ }^{134} \mathrm{Cs}$ measured contamination values are available over a more protracted time than in Lamagistère (may 1990-oct.1995, 50 values). The physical removal half-life (750 days) model combined with activities released over the preceding month lead to significant correlations all over the period $\left(\mathrm{r}^{2}=.46,31 \mathrm{plots}\right)$. All exponential models fit for the may 1990-dec.1992 period $(\mathrm{r} 2=.49-.51,25-30$ plots $)$ and all models for may1990-dec. $1991\left(\mathrm{r}^{2}=.41-.43,20-21\right.$ plots, not as high as for Lamagistère samples) (Figure2c). As to ${ }^{137} \mathrm{Cs}$, the physical removal half-life model (10950 days) combined with the releases over the month preceding the sampling date leads to $\mathrm{r}^{2}=.45$ (36 plots after removal of oct. 1990 release peak)) over the may1990-sept. 1995 and $\mathrm{r}^{2}=.56$ over the may 1990-dec.1992 periods (24 plots) (Figure 2d). Quite unexpectedly, 45 days calculated releases plotted against row moss contaminations leads to $\mathrm{r}^{2}=.52$ for the may1996-may2004 period (10 plots, no measurement over aug.1996-oct.2003). No such correlations are observed over nov.1995-july1996 $\left(\mathrm{r}^{2}=.24\right)$.

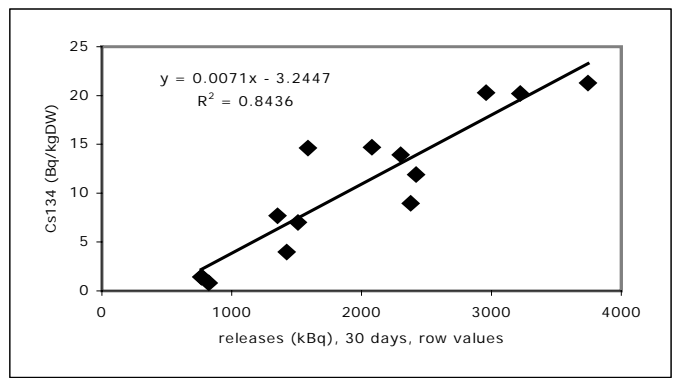

(a) Lamagistère ${ }^{134} \mathrm{Cs}$ may 90 -dec. 91

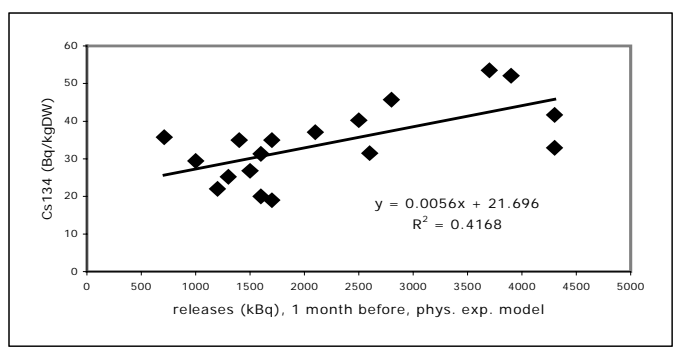

(c) Golfech ${ }^{134}$ Cs may 90-dec. 91

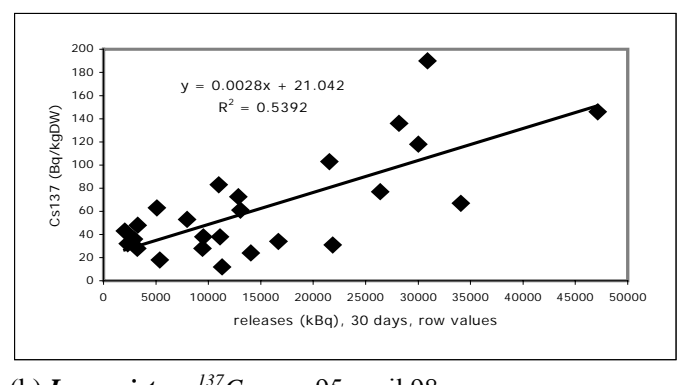

(b) Lamagistere ${ }^{137}$ Cs nov. 95 -april 98

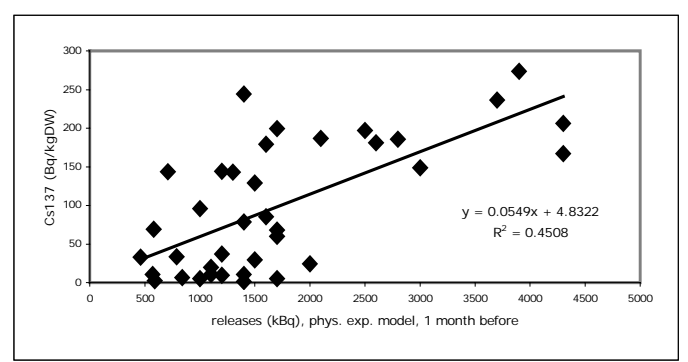

(d) Golfech $^{137}$ Cs may 90 -sept. 95

Figure 2. Mosses caesium contaminations versus halogens-aerosols atmospheric releases from the Golfech NPP. 


\section{DISCUSSION}

Several aspects deserve emphasizing and discussion.

First of all, the higher contaminations generally measured in Golfech compared with Lamagistère's are consistent with previous data [9,24,27] suggesting that in rather similar conditions, Grimmia spp. (frequently dominant in Golfech samples) are about twice as contaminated by ${ }^{137} \mathrm{Cs}$ as Tortula ruralis (frequently dominant in Lamagistère samples) (ratios $=1.5-2.17$, mean 1.9 ) and as Homalothecium sericeum (frequently dominant in Lamagistère samples) (ratios $=1.15-4$, mean 2). The mosses sampled are thus liable to explain the differential contaminations measured on each location.

Wind and rainfalls may also partly account for this phenomenon. A tentative evaluation of the wind characteristics over 1992-1994 leads to global and monthly mean frequency $\mathrm{x}$ force ratios $=2.1$ and .72-13 respectively. More generally, these two parameters are liable to influence the correlations between contaminations measured and atmospheric releases, and to contribute to the seemingly inconsistent observations related to sampling sites over the period under study.

Besides, 34 and 8 releases are respectively one and two order(s) of magnitude higher than the others. Apart from the 1990 October peak, the former occurred after October 1995, and the latter in may-august 1997. The 1990 October release was contemporary with iodine filters testings at the facility. So one can expect iodine to be the main contributor of the activity then released. The 41 other releases are contemporary with (and a consequence of) an increase of the primary coolant activity by $\sim 2$ orders of magnitude since 1995-term4, and by 3 orders of magnitude since 1997-term1, which originated in a first reactor and then a second reactor fuel leakage into the primary coolants, and decreased through a succession of peaks to the end of 2003. Some correlations suggest that he halogens-aerosols/caesium ratios, although usually not constant over time, have been modified with the increase of activities released.

Moreover, the release time, which fits best the contaminations measured in mosses tends to be shorter for ${ }^{134} \mathrm{Cs}$ than for ${ }^{137} \mathrm{Cs}$, and for the Lamagistère than for the Golfech locations. This could originate in the shorter physical removal half-time of ${ }^{134} \mathrm{Cs}$ compared to ${ }^{137} \mathrm{Cs}$ 's, and in the moss spp. sampled respectively. The latter hypothesis is consistent with [27]'s proposal that species such as Tortula spp. and Homalothecium spp. accumulation and removing times would be shorter than Grimmia spp's.

As to the removal models, the exponential ones (particularly the physical one) fit best the data for ${ }^{134} \mathrm{Cs}$ on both locations, whereas the row data are more appropriate for ${ }^{137} \mathrm{Cs}$ but for Golfech location over may 1990-sept.1995. This may originate in the differential physical removal half-life of both caesium and in an irrelevant decreasing model. The relevance of the reference values may also be considered. However, no statistical correlation comparison is available (shortage of plots). As to the $[26,14]$ linear model, it originates in contamination values recorded in the aftermath of the Chernobyl accident (midst 1987-midst 1990/end of 1986-1989 respectively) by the end of which the activities measured approached the pre-Chernobyl levels of contaminations. Quite consistently, it hardly concerns the 1990 data and not at all the post-1991 ones.

\section{CONCLUSION}

Numerous biases and uncertainties make it difficult to correlate ${ }^{134} \mathrm{Cs}$ and ${ }^{137} \mathrm{Cs}$ measured in terrestrial mosses by the Laboratoire Vétérinaire Départemental de Tarn-et-Garonne in the Lamagistère and the Golfech locations with the caesium activities released in the atmosphere from the Golfech NPP. The major ones concern the content of the monthly adding up of various isotopes by the NPP, the moss species sampled, the meteorological circumstances, the terrestrial mosses caesium accumulation and removal time. Samples processing may also be considered. However, the two series of data available (releases, mosses caesium activities) are in good correlation over large periods of time $\left(\mathrm{r}^{2}=.35\right.$ to .84$)$, which confirms the interest of using terrestrial mosses as indicators of low levels atmospheric caesium contaminations. The integration of meteorological conditions as well as of the moss species sampled, in the on-hand processing of the above data might affect the results already available. 


\section{Acknowledgments}

The authors are grateful to Conseil Général of Tarn-et-Garonne for technical contribution, and to A. Larousse, S.Mehier, G.Ormière, S.Kieser, graduate, Université Paul-Sabatier, Toulouse, for participation in data processing.

\section{References}

[1] Beaugelin-Seiller K., Caractérisation des mousses dulçaquicoles comme indicateurs de contamination radioactive, Thèse, Université de Montpellier II, 1994.

[2] Bolyuk V.O., Virchenko V.M., Ukrains’kii Botanichnii Zhurnal 54(4) (1994), 39-45.

[3] Brown D.H. and Buck G.W., New phytologist, 82 (1979), 115-125.

[4] Coughtrey P.J., Kirton J.A. and Mitchell, Environ. Pollut. 62 (1989) 281-315.

[5] Delfanti R., Papucci C. and Benco C., Sci. Total Environ. 227 (1999) 49-56.

[6] Demidchik V.V., Naidun S.N., Yablonskaya L.I., Sokolik A.I. and Yurin V.M. Russian Journal of Plant Physiology 48 (2001) 294-299.

[7] Denayer F.O., Ecotoxicité des elements traces métalliques chez les bryophytes, Thèse, Université de Metz, 2000.

[8] Draber S. and Hansen U.P., Biophysical Journal 64)(1994) 120-129.

[9] Dragovic S., Nedic O., Stankovic S. and Bacié G., J. Environ. Radioactivity XX (2004) XXX-XXX.

[10] Elsner E.F., Fink R., Höll W., Lengfelder E., Ziegler H. Oecologia 73 (1987) 553-558.

[11] Frontasyeva M.V., Yermakova Ye.V., Steinnes E. and Rahn K.A., "Study of trace elements in annual segments of moss biomonitors using epithermal neutron activation analysis: link with atmospheric aerosols" NATO Advanced Research Workshop on Monitoring and Man-Made Radionuclides and Heavy Metals Waste in Environment, Dubna, 2000, NATO Science IV Earth and Environmental Sciences 5 (2001) 165-170.

[12] Giovani C., Nimis P.L., Bolognini G., Padovani R. and Usco A., Sci. Total Environ. 157 (1994) 35-43.

[13] Godoy J.M., Schuch L.A., Nordemann D.R.J., Reis V.R.G., Ramalho M., Recio J.C., Brito R.R.A. and Olech M.A., J. Environ. Radioactivity 41(1) (1998) 33-45.

[14] Guillitte O., de Brabant B. and Gasia M.C., Mém. Soc. Roy. Bot. Belg. 12 (1990) 89-99.

[15] Holm E. and Persson R.B.R. Health Phys. 29 (1975) 43-51.

[16] Hutchinson-Benson E., Svoboda J. and Taylor H.W., Can. J. Bot. 63 (1985) 783-891.

[17] IPSN-IRSN, Suivi radioécologique des centrales nucléaires françaises, Rapports/DPRE/SERNAT.

[18] Isomura K., Higuchi M., Shibata H., Tsukada H., Iwashima K. and Sugiyama H. Radioisotopes 42(3) (1993).

[19] La Brecque J.J. and Rosales P.A. J. Radioanal. Nucl. Chem. 231(1-2) (1998) 139-142.

[20] Malmer N., Oikos, 53 (1988) 105-120.

[21] Mattson S. and Liden K., Oikos 26 (1975) 323-327.

[22] Miettinen J.K., "The present situation and recent developments in the accumulation of ${ }^{137} \mathrm{Cs},{ }^{90} \mathrm{Sr}$ and ${ }^{55} \mathrm{Fe}$ in arctic foodchain", International Symposium on Environmental Contamination by Radioactive Materials, IAEA, Vienna, 1969 pp. 145-151.

[23] Nifontova M.G., Russian Journal of Ecology 34(1) (2003) 47-51.

[24] Papastefanou C., Manolopoulou M. and Sawidis T., J. Environ. Radioactivity 9 (1989) 199-207.

[25] Rickard W.H., "Accumulation of Cs-137 in litter and understory plants of forest stands from various climatic zones of Washington", Radioecological Concentration Processes Stockholm 1966, Aberg B. and Hungate F.P. Eds (Pergamon Press, 1967) pp. 527-531.

[26] Rühling A and Tyler G., Oikos 21 (1970) 92-97.

[27] Sawidis T. and Heinrich G., Can. J. Bot. 70 (1992) 140-144.

[28] Sawidis T., Heinrich G. and Chettri M.K., Water, Air and Soil Poll. 110 (1999) 171-179.

[29] Sumerling T.J., Sci. Total Environ. 35 (1984) 251-265.

[30] Taylor F.G. and Witherspoon J.P., Health Phys. 23 (1972) 867-869.

[31] Taylor H.W., Hutchinson-Benson E. and Svoboda J., Can. J. Bot. 63 (1985) 792-796.

[32] Triulzi C., Nonnis Marzano F and Vaghi M., Annali di Chimica 86 (1996) 11-12.

[33] White P. and Broadley M., New Phytologist 147 (2000) 241-256. 